of copyright law. In his preface Shaw accurately states that copyright is obtained merely by publishing with the proper notice, but then he waits until the sixth and ninth chapters to offer the caveat that certain other requirements are also necessary.

Members of the publishing trade will undoubtedly object with angelic indignation to Shaw's contention that in having the copyright in their name, believing that they "may gain more or get better protection," they do so "at the expense of the author." This stand, along with substantiated examples of confusion in the law, forms the basis for Shaw's proposal to redraft the copyright statute and make copyright the exclusive domain of authors. The reviewers concede that this position may be sound in theory, but from a practical standpoint they query whether any substantial change would be effected in the light of standardized contracts and practices in the trade.

Unquestionably the most valuable portion of the book as far as librarians are concerned is Chapter XVIII which deals with literary property and scholarly institutions. The constantly haunting legal problems of facsimile reproduction, such as by photostat and microfilm, recompiling and the replacement of pages is expertly dealt with in a lucid manner. This chapter in effect reveals one more facet of the classic problem facing libraries with regard to the acceptance o, rejection of manuscripts, theses and other materials, namely, exactly what is it that the donor has a right to give in the first place? After perusing the chapter with this aspect in mind, librarians are well advised to re-examine their collections. Some startling discoveries and reactions are assured.

Each of the pithy chapters ends with a summary of its contents, which is useful both as a preliminary survey of each chapter and a final thought provoking reappraisal. The text is well documented although the references are inconveniently placed at the end of the book in a separate section and the term "C.O.B." is constantly used without any indication that it is an abbreviation for Copyright Office Bulletin. Bibliophiles and perfectionists may object to the price of six dollars placed on the volume by author-publisher Shaw, pointing out the uneven inking, slick paper and deficiencies in the binding process. Notwithstanding this, the treatise is highly recommended for librarians and others who believe that it is their obligation to have more than a smattering of the concepts of literary property and copyright law.-Harry Bitner and Mortimer Schwartz, Columbia University Law Library.

\section{Educational Measurement}

Educational Measurement. Ed. by E. F. Lindquist and published by the American Council on Education. Washington, D.C. 195 I, 81 9p. \$6.00.

This is a comprehensive handbook and textbook on the theory and technique of educational measurement on the advanced graduate level. The volume was planned by the Committee on Measurement and Guidance of the American Council on Education in 1945 to overcome the lack of reference and instructional materials in those universities offering graduate training in educational measurement.

Seventy experts in the measurement field, under the general editorship of E. F. Lindquist, participated in the writing of this volume. The proceeds from the sale are to go into a permanent Measurement Book Project Fund which will be used for future revisions of the work.

The book contains 18 chapters divided into three parts: The Functions of Measurement in Education; The Construction of Achievement Tests; and Measurement Theory. Ample charts, graphs, illustrations and selected references are furnished throughout. For those teacher-training institutions not offering graduate courses in measurement, this work may well find a place in the reference collection to supplement works such as the Encyclopedia of Educational Research.Irving A. Verschoor, Columbia University.

\section{The H. W. Wilson Company}

The H.W.Wilson Company; Half a Century of Bibliographic Publishing. By John Lawler. Minneapolis, University of Minnesota Press, 1950, \$3.00.

Lawler's The H.W.Wilson Company is presumably an example of the growing tendency of historical scholarship to be concerned with the critical analysis of the emergence and development of American commercial and industrial enterprise. But in the pages 
of this book one will not find the objectivity and dispassionate appraisal that have characterized many other writings of this genre. On the contrary, here is a panegyric to the honor and success of Halsey W. Wilson, the company he founded and his associates in the undertaking.

Mr. Wilson succeeded in subject bibliography, the history of which is strewn with the wreckage of ill-fated enterprises. Almost the only man who has made bibliography profitable, he created an organization that is characterized by "an innate sense of duty, respect for the company's founder, delight in the challenge of a responsible job, recognition of its opportunities, pride in accomplishment" (p.I39). His was a staff that suffered from "a strange disease ... called the Bibliographical Urge" (p.I39), a staff that enjoyed "conditions of work [that were] favorable" (p.I40), a "sense of adventure" (p.I40), a "policy of welcoming women in a period when prejudice barred them from most business firms" (p.140), an "encouragement of initiative on the part of its workers" (p.I40), in short a congenial "family" (p.I4I).

This reviewer does not wish to belittle the achievements of the Wilson Company, though the author himself almost does as much by the very excesses of his praise. The Wilson bibliographic services are a substantial contribution to the development of bibliographic organization in the English-speaking world, and as such they merit a really serious studv based on a solid understanding of the problems of, subject bibliography. But the pages before us fail to perform this task.

The work itself is divided into three parts: Part I: The Past, in which the librarian who is reasonably familiar with the Wilson services will discover little of importance that is new or significant. Part II: The Present, which contains, among other matters, two quite excellent chapters on the compiling of the C.B.I. and the periodical indexes, the only part of the entire work that makes any substantial contribution to the informed librarian's knowledge of the subject. The work concludes with a series of appendices that supply listings of the Wilson publications, and a "Note on Sources," which, incidentally, seem to be far more voluminous than was necessary for the execution of the work.-Jesse H. Shera, Graduate Library School, University of Chicago.

\section{College Fund-Raising}

Fund-Raising for the Small College. By Edward L. Hawthorne. New York, Columbia University, Teachers College, Bureau of Publications, 1950, 25 Ip. \$3.0o.

This book should be required reading for every college president and his chief officer in charge of fund raising. Here, in slightly over 200 pages, Mr. Hawthorne presents a first-rate analysis of the problems that are involved in financing the small colleges of this country.

While the general statistics and information on philanthropic giving will certainly prove instructive, college officers are urged to study carefully the last two sections which deal with the various considerations that must be taken into account in developing a financial program for a small college.

The writer has correctly stressed the importance of preliminary planning and organization. Too many college fund-raising programs have started on the assumption that there is nothing much more to do than to ask for money. This book shows how imperative it is to make a careful analysis of the public from whom the funds are to be solicited, the importance of preparing this public for a request for funds and the organization necessary to make such a program a manageable one.

Mr. Hawthorne has not confined himself to generalizations of fund raising but presents a bill of particulars on the best way to go about it. To those who are just starting a fund-raising program, a careful reading and rereading of this book is strongly recommended. Those who have already had some years' experience will wish that they had had an opportunity to read it before they started their endeavors.-James A. Perkins, Carnegie Corporation of New York.

\section{Texas A. and M. Survey}

"Report of a Survey of the Library of the Texas A. and M. College October, I949 to February, 1950." By Robert W. Orr and William H. Carlson. College Station: Texas A. and M. College, 1950, 167p. (Mimeographed).

The surveys of land-grant college libraries continue to add to our information concerning an important arm of librarianship in the 